\title{
Cechy polskiego języka biznesu jako języka specjalistycznego w początkowym etapie ksztaltowania się (na podstawie „Czasu” z lat 1870- 1914)
}

\section{Features of business language as a special language at the initial stage of its development (based on the material from Czas)}

\author{
Paulina Gajda \\ KATEDRA WSPÓŁCZESNEGOJ ĘZYKA POLSKIEGO, \\ WYDZIAE POLONISTYKI UNIWERSYTETU J AGIELLOŃSKIEGO, \\ UL. GOŁĘBIA 20, 30-007 KRAKÓW \\ paula.gajda@uj.edu.pl
}

\begin{abstract}
The aim of the article is to present a specific features of business language at the initial stage of its development (years: 1870-1914). This stage provides an interesting research material and its analysis is necessary to have a full overview of business language as a specialized variety of contemporary Polish. The article concerns various aspects of this issue: diversity of business subject fields, the primacy of cognitive function over the communicative function and specific features of the grammatical and lexical scope. All features stem from the specific communicative situations in which business language as a language for specific purposes occurs. The analysis embraces the linguistic material that comes from the Krakow newspaper Czas.
\end{abstract}

\section{Wprowadzenie}

Rosnące znaczenie socjalnych odmian polszczyzny, w tym nie tylko języków specjalistycznych, ale i języków środowiskowych, skutkuje koniecznością systematycznego ich badania. Najnowszy dorobek językoznawczy w tym zakresie coraz częściej koncentruje się wokół języka biznesu, którego prężny rozwój jest wynikiem postępujących przemian ekonomicznogospodarczych. Badacze podejmujący to zagadnienie zwykle zawężają jednak język biznesu do wybranej odmiany, takiej jak: business communica- 
tion (Ćwiklińska, Szadyko 2005) czy mówiony język biznesu (Kochan 2010). J eżeli zaś podejmują próbę całościowej analizy języka biznesu, najczęściej czynią to z perspektywy translatorycznej (Ćwiklińska 2006) bądź glottodydaktycznej (Cudak, Tambor 1996; Łyda 1997; Mamet 1997, 2002; Wilk-J anik 2000). Dodać należy, iż badania języka biznesu zasadniczo dotyczą współczesnej jego postaci analizowanej w ujęciu synchronicznym. J ęzyk biznesu jest przy tym traktowany jako język działalności stosunkowo nowej, nieposiadającej tradycji na gruncie polskim.

Konieczne wydaje się jednak zweryfikowanie omówionego wyżej podejścia badawczego. Nie możemy bowiem zapominać, iż polska gospodarka wolnorynkowa w postaci rozwiniętej funkcjonowała już w XIX wieku. Po roku 1870 rozpoczął się także niezwykle istotny okres dla polskich języków specjalistycznych, w tym polskiego języka biznesu. J ak zauważa Stanisław Gajda, w tym czasie niemal na nowo tworzy się polskie środowisko naukowo-techniczne, którego
„zasługą jest umiejętne wypracowanie wielu języków specjalistycznych i uczynienie z nich narzędzia porozu- miewania się szerokiego kręgu użytkowników." (Gajda 1997: $14-15)^{1}$

W wyniku sprzyjających warunków politycznych i gospodarczych polski język biznesu na przełomie XIX i XX wieku nabral już charakteru systemowego. Co więcej, w odniesieniu do tego czasu możemy już mówić o funkcjonowaniu języka działalności biznesowej w rozumieniu bliskim współczesnemu, tj. działalności:

1. realizowanej w warunkach gospodarki wolnorynkowej,

2. z inicjatywy samodzielnych podmiotów,

3. z inicjatywy podmiotów gospodarujących prywatnym kapitałem,

4. ukierunkowanej na osiągnięcie zysku,

5. podejmowanej pomimo ryzyka (W. Pomykało (red.) 1995: 77- 78).

Początkowy etap rozwoju języka biznesu, datowany na lata 1870-1914, dostarcza interesującego materiału badawczego, którego analiza jest warunkiem koniecznym do uzyskania pełnego oglądu języka biznesu jako specjalistycznej odmiany współczesnej polszczyzny.

Niniejszy artykuł jest próbą całościowego spojrzenia na system języka biznesu kształtujący się we wskazanym wyżej okresie. W kolejnych częściach omówione zostaną poszczególne jego właściwości uznane za charakterystyczne, a nawet obligatoryjne. Uwzględnione zostaną przy tym cechy będące pochodnymi specyfiki sytuacji komunikacyjnej w języku biznesu jako języku specjalistycznym lat 1870-1914.

Poszczególne właściwości omówione zostaną na podstawie specjalistycznej rubryki dziennika „Czas” obejmującej w całości teksty poświęcone zagadnieniom biznesowym. W latach 1870 - 1914 dział ten sygnowano ja-

1 Uściślając, uwaga odnosi się do lat 1871-1918. Za granicę końcową badań, w odróżnieniu od propozycji S. Gajdy, uznany został jednak rok 1914, a więc data wybuchu I wojny światowej, która zahamowała rozwój słownictwa biznesowego. 
Paulina Gajda: Cechy polskiego języka biznesu jako języka specjalistycznego w początkowym etapie ksztaltowania się

ko: Gospodarstwo przemyst i handel; Gospodarstwo, przemyst i handel; Gospodarka, przemyst, handel; Dziat ekonomiczny bądź jako Wiadomości ekonomiczne.

\section{Zróżnicowanie przedmiotowe języka biznesu w latach 1870-1914}

Kryterium tematu komunikacji pozwala na wskazanie pierwszej właściwości języka biznesu, jaką jest szeroki wachlarz przedmiotowo-tematyczny. Cecha zróżnicowania przedmiotowego nie budzi wątpliwości, kiedy myślimy o współcześnie funkcjonującym języku biznesu. Podkreślić jednak należy, iż wysoki stopień złożoności zarówno dziedziny biznesu, jak i języka, który ją obsługiwał, możemy zaobserwować już na przełomie XIX i XX wieku. Co więcej, działalność biznesowa już w latach 1870-1914 była podejmowana zarówno w skali mikro-, jak i makroekonomicznej.

Z punktu widzenia mikroekonomicznego biznesem była każda „(..) działalność dochodowa określonego podmiotu, wymagająca inicjatywy i kapitału, obarczona większym lub mniejszym ryzykiem nieuzyskania dochodu lub nawet utraty kapitału" (Pomykało (red.) 1995: 78). Gospodarka wolnorynkowa, rozwijająca się w badanym okresie, pozwalała na podejmowanie wszelkiego rodzaju działalności w tym rozumieniu. Biznesem była więc aktywność handlowa, zarówno hurtowa, jak i detaliczna, ukierunkowana na pośredniczenie w obrocie towarów pomiędzy producentami i konsumentami. Działania handlowe podejmowano nie tylko na rynku krajowym, doskonale rozwinięta była również wymiana handlowa $\mathrm{z}$ podmiotami zagranicznymi. Biznesem w skali mikro- była także działalność wytwórcza prowadząca do wyprodukowania i wyceny produktu - zarówno w postaci materialnego dobra, jak i usługi. Było to wreszcie inwestowanie na gieldzie papierów wartościowych, gdzie przedmiotem obrotu, mającego na celu pozyskanie lub rozmnożenie kapitału, były tzw. efekta, szerzej znane jako akcje, obligacje, weksle czy listy zastawne.

Działalność gospodarcza była podejmowana przez przedsiębiorców i przedsiębiorstwa o zorganizowanej strukturze, zarówno na poziomie wewnętrznej organizacji, jak i w zakresie „integracji zewnętrznej”, którą w pewnym uogólnieniu - sprowadzić należy do kooperacji z otoczeniem: klientelą, konkurencją, instytucjami finansowymi² etc. (Potocki, Winkler, Żbikowska 2011: 148, 150). Współpraca tego typu była już podstawą biznesu w skali makroekonomicznej rozumianego jako:

„powszechna forma bytowania w społeczeństwie jednostek przedsiębiorczych, które (...) powołują do życia rozmaite układy stosunków społecznych i zależności, nieraz układy wysoce złożone, zawsze jednak ze sobą powiązane i tworzące całość, która oddziałuje na gospodarkę kraju, a także na całe społeczeństwo." (Pomykało (red.) 1995: 78)

2 Szczególną rolę wśród instytucji zewnętrznych odgrywały banki i wszelkie instytucje oszczędnościowo-kredytowe. 
Każda forma biznesu, zarówno na poziomie jednostkowego przedsiębiorstwa, jak i spółek podmiotów gospodarczych, łączyła się z zagadnieniem negocjacji, a więc szeregiem posunięć uruchamianych w celu osiągnięcia jak najkorzystniejszego rozwiązania w sytuacji, gdy zachodził choćby częściowy konflikt interesów (Nęcki 1994: 16).

Funkcjonowanie przedsiębiorstwa, podobnie jak dziś, nie było możliwe bez rejestrowania, klasyfikacji i interpretacji danych o sytuacji finansowej jednostki. Cały zbiór operacji finansowych, wpływających na zmianę stanu majątkowego przedsiębiorstwa, był więc przedmiotem rachunkowości, w tym: księgowości, kalkulacji czy sprawozdawczości finansowej (Kołaczyk 1999: 25).

Omówione wyżej zestawienie zagadnień czy też dyscyplin, wobec których słowo 'biznes' w latach 1870-1914 pozostawało terminem nadrzędnym, nie pretenduje do miana zestawienia kompletnego. J est jedynie zarysem służącym ukazaniu niejednolitości dziedziny, której język stanowi obiekt rozważań w niniejszym artykule. Przedmiot tego języka od początku jest równie złożony. Jak zauważa M. Kochan „istnieje pewien rdzeń, część wspólna, swoista »filozofia języka« i wspólne minimum leksykalne, obecne w różnych odmianach" (Kochan 2010: 170). Równocześnie jednak odmiany charakterystyczne dla poszczególnych subdziedzin funkcjonowały i nadal funkcjonują w układzie poziomym, wyróżniając się zorientowaniem na konkretne segmenty rzeczywistości.

\section{Prymat funkcji poznawczej nad funkcją ko- munikatywną}

Świat biznesu w skali mikro- i makroekonomicznej istnieje dzięki funkcji komunikatywnej obsługującego go języka. Uszczegóławiając, język biznesu jako język specjalistyczny od początku służy porozumiewaniu się na temat obiektów charakterystycznych dla poszczególnych segmentów rzeczywistości biznesowej. Nie jest to jednak jedyna jego funkcja. Celem języka biznesu jako narzędzia pracy zawodowej jest również - a nawet przede wszystkim - umożliwienie użytkownikom kategoryzowania tychże obiektów, a zatem spelnienie funkcji poznawczej (Lukszyn (red. nauk.) 2005: 40). Innymi słowy funkcja komunikatywna jest podporządkowana funkcji poznawczej na każdym etapie rozwoju języka biznesu. W początkowej fazie kształtowania się owego języka zależność ta była jednak szczególnie istotna.

Każdy rodzaj działalności biznesowej podejmowany jest z założeniem osiągnięcia sukcesu, przede wszystkim w wymiarze zysku finansowego. Sukces zaś jest wynikiem ogólnego rozwoju struktury instytucjonalnej, założonej w celach biznesowych, na który rzutuje rozwój każdej związanej z nim jednostki. By dana działalność biznesowa, początkowo podejmowana w ograniczonym zakresie, mogła się rozwinąć, konieczne jest wytworzenie, udoskonalenie, a następnie wykorzystanie przez jednostki ją podejmujące 
Paulina Gajda: Cechy polskiego języka biznesu jako języka specjalistycznego w początkowym etapie ksztaltowania się

potrzebnej wiedzy specjalistycznej. Owo uporządkowanie, zachowanie czy też zastosowanie wiedzy dokonuje się zaś dzięki procesom komunikacji3 .

Funkcja poznawcza języka biznesu realizuje się zatem zarówno na poziomie de Saussure'owskiego langue, jak i parole. Płaszczyzna systemowa rejestruje doświadczenia poznawcze specjalistów w danej dziedzinie działalności biznesowej, odzwierciedlając tym samym specyficzny dla nich sposób kategoryzacji świata w postaci wiedzy specjalistycznej. Ponadto dzięki temu, że język jako system stanowi reprezentację mentalną rzeczywistości, umożliwia również "dalsze abstrakcje”, „przeprowadzanie rozumowan” (Grzegorczykowa 1991: 20), a więc twórcze wykorzystanie pozyskanej wiedzy, niezbędne w procesie rozwoju jednostki.

Wiedza nieustannie udoskonalana przezjednostkę, dzięki płaszczyźnie parole, a zatem w toku komunikacji będącej wzajemną wymianą aktów mowy, jest przekazywana pozostałym członkom danej wspólnoty specjalistycznej. Dlatego też wśród form organizacji komunikacji już w przedsiębiorstwach z przelomu XIX i XX wieku pożądane były metody takie, jak: zebrania, posiedzenia, konferencje, odprawy, narady:

„Po załatwieniu przedwstępnych formalności otwarcia posiedzenia [pogrubienie - P.G.] (...) dyrektor Banku $\mathrm{hr}$. Karol Scipio odczytał sprawozdanie Zarządu z czynności za rok ubiegły wraz z bilansem i rachunkiem zysków i strat." („Czas” 1888, nr 103 (4 V): 3)

„Po przyjęciu do wiadomości sprawozdania z ostatniego walnego zgromadzenia [pogrubienie - P.G.] (...) prezes przedstawił w zarysie dotychczasowy przebieg organizacyi Spółki.” („Czas” 1909, nr 105 (10 V): 3)

\begin{abstract}
„Aby Wydział Tow. był w stanie poczynić wcześnie swoje zarząadzenia, uprasza P. T. członków Towarzystwa, ażeby o swoim uczestnictwie w Walnem Zgromadzeniu [pogrubienie - P.G.] zawiadomić raczyli Wydział najpóźniej do 30 lipca b. r.” („Czas” 1888, nr 157 (12 VII): 3)
\end{abstract}

„Ostatni punkt porządku dziennego [pogrubienie P.G.] stanowily wnioski członków.” („Czas” 1895, nr 48 (27 II): 2)

Komunikacja zespołowa prowadziła do doskonalenia całej wspólnoty, w konsekwencji zaś umożliwiała rozwój łączącej ją instytucji. To zaś -

3 Por. rozważania F. Gruczy (Grucza F. 2002: 25), S. Gruczy (Grucza S. 2008: 79) i J. Lukszyna (Lukszyn 2002: 44, Lukszyn (red. nauk.) 2005: 32) na temat funkcji poznawczej języków specjalistycznych. 
w dalszej perspektywie - skutkowało rozwojem całej dziedziny, w ramach której funkcjonowała owa instytucja.

Funkcja poznawcza języka biznesu w analogiczny sposób realizowała i nadal realizuje się $\mathrm{w}$ toku integracji danej instytucji $\mathrm{z}$ otoczeniem zewnętrznym - bardziej lub mniej związanym z jej profilem działalności. Specjaliści z danej branży poprzez komunikację z otoczeniem od początku kształtowali, a później rozwijali wiedzę otoczenia na temat organizacji czy dyscypliny, którą reprezentowali, składali stosowne obietnice:

„Listy zastawne galicyjskiego towarzystwa kredytowego ziemskiego nie pojawiły się dotąd jeszcze w kurscetlu gieldy wiedeńskiej, ale mamy już zapewnienie Dyrekcyi [pogrubienie - P.G.], że się o przywrócenie ich notacyi na pomienionej giełdzie niebawem postara.” („Czas” 1876, nr $231(10 \mathrm{X}): 3)$

„Kończąc to sprawozdanie, wyraża dyrekcya dzięki szanownemu P. T. obywatelstwu, jakoteż wszystkim odbiorcom za łaskawe popieranie licznemi swemi zamówieniami celów Towarzystwa, a zarazem zapewnia [pogrubienie P.G.], że i nadal dołoży wszelkich starań, aby ich pod każdym względem zadowolić.” („Czas” 1888, nr 69 (23 III): 3)

prośby, wnioski i petycje:

„Wiceprezes Tow. roln. p. Franciszek Paszkowski (...) prosil o poparcie u Ministra [pogrubienie - P.G.] w kierunku objawionego kilkakrotnie życzenia otrzymania kredytu na melioracye gruntowe.” („Czas” 1876, nr 106 (10 V): 3)

równocześnie - w toku komunikacji zwrotnej - udoskonalając swoją wiedzę na temat oczekiwań klientów, rozwiązań wprowadzanych przez konkurencję, możliwości wsparcia ze strony innych instytucji (banków, organizacji medialnych, kulturalnych bądź politycznych). Zdobyte doświadczenia poznawcze wykorzystywali potem w komunikacji wewnętrznej ukierunkowanej na rozwój przedsiębiorstwa i dziedziny swojej działalności.

\section{Specyfika gramatyczna i leksykalna}

Rozważania na temat funkcji języka biznesu w początkowej fazie kształtowania się podsumować możemy, nawiązując do stwierdzenia Franciszka Gruczy (1994: 8), zgodnie z którym język biznesu, jako język specjalistyczny, nigdy nie był wyłącznie narzędziem służącym porozumiewaniu się. Jego nadrzędną rolą było i nadal pozostaje umożliwienie użytkownikom zarówno jednostkom, jak i grupie - kognitywnego oraz praktycznego roz- 
Paulina Gajda: Cechy polskiego języka biznesu jako języka specjalistycznego w początkowym etapie ksztaltowania się

woju. Funkcja ta - dodajmy - od początku realizowana była przede wszystkim na poziomie warstwy leksykalno-semantycznej języka biznesu.

O ile bowiem morfologia czy syntaktyka języka biznesu zasadniczo pokrywały się z analogicznymi płaszczyznami języka ogólnego, a różnice polegały na większej częstotliwości wykorzystywania pewnych struktur na poziomie:

1. słowotwórczym, takich jak:

a. nominalizacje odczasownikowe,

np. żyrowanie, reeskontowanie, spekulowanie, ofiarowanie, ofrachtowanie,

b. struktury złożone,

np. nowonabywca, spótposiadanie, wspótwłaściciel, petnomocnik, rachmistrz, baubanki, sprawozdanie (kasowe),

c. struktury z rdzeniem pochodzenia grecko-łacińskiego,

np. spekulacja, subskrybować, asygnacja, akcja, skrypt (dłużny), operat (szacunkowy),

2. fleksyjnym, takich jak:

a. elementy strony biernej,

np. „produkt przez kupców krakowskich rozkupiony zostal” ("Czas” 1870, nr 14 (19 I): 3), „zboże przez krakowskich kupców rozkupione zostało” („Czas” 1879, nr 3 (4 I): 2), „zboże zakupionem zostało przez kupców zbożowych” ( „Czas” 1879, nr 202 (3 IX): 2), „wartość przez maklera została wyjaśnioną” („Czas” 1888, nr 113 (18 V): 2),

b. formy nieosobowe czasowników,

np. sprzedano, nabyto, zezwolono, eskontowano, domicyliowano, przyjęto,

c. formy 1 os. l. mn.,

np. „Oto najprzód mamy porządek dzienny zebrania ogólnego (...)” („Czas” 1876, nr 20 (26 I): 3), „Ze sprawozdania, które w tej mierze dyrekcya przedłożyła ogólnemu zgromadzeniu wyjmujemy następne szczegóły: (...)" („Czas” 1871, nr 38 (16 II): 3),

3. syntaktycznym, takich jak:

a. skupienia terminologiczne,

np. ajent handlowy, klika spekulacyjna, spekulacja kupiecka, centrum handlowe, gielda towarowa, rynek zagraniczny, spekulacja terminowa,

b. konstrukcje bezpodmiotowe,

np. „produktów nie dowieziono” („Czas” 1876, nr 20

(26 I): 3), „wyłożono do subskrypcyi” („Czas” 1914, nr 52

(25 II): 3), „zbywano obligacye” („Czas” 1873, nr 28 (4 II): $3)$,

c. hipotaksa,

np. „Świeże jeszcze wrażenie, jakie sprawiła zyskana pewność, że większa część zakładów finansowych austry- 
ackich nie zapłaci ani kuponu procentowego, ani dywidendy, nie mogło być bodźcem do zwyżki (...).” („Czas” 1876, nr 7 (11 I): 3), „Chcąc ten kurs waluty utrzymać przynajmniej do jesieni, licząc na eksport zboża, a tem samem na ruch tratt przesyłanych z Anglii w zapłacie za zboże, minister mniemał, że, niszcząc znaczną masę banknotów (...) zmusi poniekąd świat finansowy do robienia sobie pieniędzy przez ciągnięnie tratt na Londyn.” („Czas” 1876, nr 160 (16 VII): 3),

o tyle leksyka w dużej mierze była już odrębna. Co więcej, swoistą odrębnością na poziomie leksykalnym charakteryzowała się każda z funkcjonalnych odmian języka biznesu. Wszystkie bowiem były językami wiedzy specjalistycznej będącej reprezentacją mentalną nieco odrębnego segmentu rzeczywistości. W każdym z subjęzyków biznesu (języku handlu, giełdy, produkcji etc.) znajdziemy więc terminy będące znakami pojęć pewnych obiektów (np. w języku giełdy: obligacje pierwszeństwa, listy zastawne, konsole, cedula gieldowa), instytucji (np. w języku handlu: centrum handlowe, giełda towarowa, giełda zbożowa, targowica) czy czynności (np. wjęzyku giełdy: eskontować (weksle), emitować (papiery wartościowe), konwertować (listy zastawne)) typowych tylko dla tej dziedziny, którą ów język obsługiwał.

Pomimo wspomnianej niejednolitości, w terminologii biznesowej z lat 1870-1914 zaobserwować możemy znamiona systemowości, w tym systemowości na poziomie relacji paradygmatycznych. J ednostki te nie realizowały funkcji znakowej w izolacji, ale jako komponenty zbiorów terminologicznych odsyłających do większych obszarów rzeczywistości pozajęzykowej będącej przedmiotem zainteresowania danej dziedziny biznesu.

Podstawowymi zbiorami terminów, uporządkowanych wewnętrznie, są pola terminologiczne, których kształt i charakter oddaje aktualny stopień specjalizacji poszczególnych grup językowych zarówno w aspekcie poznawczym, jak i praktycznym. Siatka tego typu zbiorów w omawianym okresie przedstawia się następująco:

1. giełda papierów wartościowych,

2. dystrybucja i handel towarami,

3. należności i świadczenia,

4. przedsiębiorstwo,

5. przedsiębiorca,

6. produkcja,

7. rachunkowość i finanse,

8. negocjacje,

9. oszustwa i nadużycia.

Wskazane wyżej pola terminologiczne wypelniaja mniejsze układy jednostek terminologicznych, które możemy określić jako subpola terminologiczne. Każde z nich jest mniej lub bardziej samodzielne tematycznie. Przykładem niech będzie siatka subpól w ramach pola 'dystrybucja i handel towarami':

1. podmiot przedsięwzięć handlowych (podmiot działań), 
Paulina Gajda: Cechy polskiego języka biznesu jako języka specjalistycznego w początkowym etapie ksztaltowania sie

2. adresat przedsięwzięć handlowych (adresat działań),

3. pośrednik przedsięwzięć handlowych (pośrednik działań/

podmiot przedsięwzięć handlowych podejmowanych w imieniu kogoś innego),

4. przedmiot transakcji handlowych,

5. przestrzeń fizyczna transakcji handlowych,

6. przestrzeń wyobrażona transakcji handlowych,

7. działania handlowe,

8. zjawiska, procesy, stany w sferze handlu,

9. dokumenty handlowe.

J ednostki wypelniające każde z wyznaczonych pól i subpól terminologicznych, definiowane jako znaki językowe, oznaczają pojęcia (koncepty) w układzie relacji semantycznych ${ }^{4}$ (Lukszyn, Zmarzer 2006: 37) czyli w ramach paradygmatów (mikrosystemów) terminologicznych (Lukszyn, Zmarzer 2006: 57). Do najważniejszych relacji, będących podstawą ich zaistnienia - w początkach kształtowania się terminologii biznesowej należą:

1. relacje hierarchiczne o charakterze:

a. generycznym, np.

i. $\uparrow$ rynek

$\downarrow$ rynek zagraniczny, rynek zbytu, rynek zbożowy

ii. $\uparrow$ spekulacja

$\downarrow$ spekulacja kupiecka

b. partytytywnym (meronimicznym), np.

i. $\uparrow$ towarzystwo

$\downarrow$ agencja towarzystwa

ii. $\uparrow$ oblig

$\downarrow$ kupon

iii. $\uparrow$ weksel

$\downarrow$ domicyl

2. relacje antonimii, np. haussa $\leftrightarrow$ baissa, eksport $\leftrightarrow$ import,

3. relacje bliskoznaczności semantycznej, np. przedający $\equiv$

sprzedajacy, konsument $\equiv$ konsum, komisant $\equiv$ komisjonariusz, ofiarowanie $\equiv$ zaofiarowanie,

4. relacje asocjacyjne (Nagórka 2011: 86-88), w tym:

a. relacje konwersji na linii: pojęcie surowca - pojęcie produktu, np. surowica $\approx$ fabrykat, pojęcie obiektu początkowego pojęcie obiektu końcowego, np. weksel $\approx$ indos,

b. relacje implikacji pomiędzy pojęciem czynności/procesu a pojęciem produktu, np. domicylować $\approx$ domicyl, eskontować $\approx$

4 Tym samym pole terminologiczne jest zbiorem jednostek, który na płaszczyźnie poznawczej pokrywa odpowiadające mu pole pojęciowe rozumiane jako „bezpośrednie otoczenia danego pojęcia w systemie pojęciowym” (Lukszyn (red. nauk.) 2005: 85-86). 
eskont lub pojęciem przyczyny i pojęciem skutku, np. spekulacja $\approx$ handel terminowy, ruch towarowy $\approx$ zwyżka,

c. relacje predykacji o charakterze: pojęcie czynności/obiektu pojęcie wykonawcy, np. zakupno $\approx$ konsum, spekulacja $\approx$ spekulant, pojęcie czynności - pojęcie adresata, np. intabulacja $\approx$ dtużnik, zaofiarowanie $\approx$ klientela, pojęcie czynności/ obiektu - pojęcie środowiska, np. spęd $\approx$ targowica, transakcja $\approx$ centrum handlowe, pojęcie obiektu - pojęcie właściwości obiektu, np. giełda towarowa $\approx$ ogólna, faktura $\approx$ oryginalna,

d. relacje towarzyszące, tj. zależności pomiędzy pojęciem czynności/ procesu/obiektu a pojęciem narzędzia/instrumentu jako czynników sprzyjających lub pomiędzy pojęciem czynności/ procesu/ obiektu a pojęciem czynnika niesprzyjającego, np. handlarz $\approx$ petycja, ruch towarowy $\approx$ taryfa.

\section{Podsumowanie}

Obserwacje, których wyniki starałam się przedstawić w artykule, uprawniają do stwierdzenia, iż język biznesu nie jest nową odmianą polszczyzny, powstałą w wyniku rozwoju gospodarczego, jaki dokonał się po transformacji ustrojowej z 1989 r. Wszelkie właściwości, nadające mu status języka specjalistycznego, mają o wiele bogatszą tradycję na gruncie polskim. Uświadomienie sobie tego faktu stanowi pierwszy krok do podjęcia interesujących badań o charakterze diachronicznym dostarczających wiedzy o procesach, jakie ukształtowały nie tylko system współczesnego języka biznesu, ale również systemy innych języków specjalistycznych, a nawet polszczyzny ogólnej. Należy bowiem pamiętać, iż - pomimo niewątpliwych różnic natury formalnej, jak i funkcjonalnej - języki te nie pozostają bez wzajemnego wpływu na siebie. Ogół skomplikowanych zależności między nimi - zachodzących przede wszystkim na poziomie paradygmatów semantycznych - wymaga, dodajmy, pogłębionych analiz ciągów syntagmatycznych. Kontekst składniowy odzwierciedla bowiem różnorodność możliwego zastosowania poszczególnych jednostek leksykalnych. Pozwala również dostrzec mechanizmy procesów kształtowania się nowych elementów danego systemu leksykalnego bądź zmiany zakresu ich struktury konceptualnej, w tym zmiany segmentu rzeczywistości, do której pierwotnie odsyłały. 
Paulina Gajda: Cechy polskiego języka biznesu jako języka specjalistycznego w początkowym etapie ksztaltowania się

\section{Bibliografia}

Cudak, R., Tambor, J. 1996. Czy istnieje polski język biznesu? w: OstromeckaFrączak, B. (red.) Kształcenie specjalistyczne cudzoziemców. Łódź: Wydawnictwo Uniwersytetu Łódzkiego, s. 109-120.

Ćwiklińska, J . 2006. Źródła zakłóceń semantycznych w międzynarodowym komunikowaniu biznesowym. „Zeszyty Naukowe Kolegium Gospodarki Swiatowej", nr 19, s. 137-147.

Ćwiklińska, J., Szadyko, S. 2005. Obszary wiedzy specjalistycznej w wybranych wariantach języka business communicaton. w: Lewandowski, J., Kornacka, M. (red.) Języki Specjalistyczne 5. Teksty specjalistyczne w kontekstach zawodowych i tlumaczeniach. Warszawa: Katedra J ęzyków Specjalistycznych Uniwersytetu Warszawskiego, s. 81-88.

Gajda, S. 1997. Polskie języki specjalistyczne dawniej i dziś. w: Arabski, J . (red.) Jezyki specjalistyczne. Język biznesu. Materiały konferencyjne. Katowice: Wyższa Szkoła Zarządzania Marketingowego i J ęzyków Obcych w Katowicach, s. 7-24.

Grucza, F. 1994. O językach specjalistycznych (= technolektach) jako pewnych składnikach rzeczywistych języków ludzkich. w: Grucza, F., Kozłowska, Z. (red.) J ęzyki specjalistyczne. Materiały z XVII Ogólnopolskiego Sympozjum ILS UW Warszawa 9-11 stycznia 1992. Warszawa: Akapit, s. 7-27.

Grucza, F. 2002. Języki specjalistyczne - indykatory i/ lub determinanty rozwoju cywilizacyjnego. w: Lewandowski, J. (red.) J ęzyki Specjalistyczne 2. Problemy technolingwistyki. Warszawa: Katedra J ęzyków Specjalistycznych UW, s. 9-51.

Grucza, S. 2008. Lingwistyka języków specjalistycznych. Warszawa: Wydawnictwo Euro-Edukacja.

Grzegorczykowa, R. 1991. Problem funkcji języka i tekstu w świetle teorii aktów mowy. w: Bartmiński, J., Grzegorczykowa, R. (red.) J ęzyk a kultura, t. 4, Funkcjejęzyka i wypowiedzi. Wrocław: Wiedza o kulturze, s. 11-28.

Kochan, M. 2010. Mówiony język biznesu. w: Milewska-Stawiany, M., RogowskaCybulska, E. (red.) Polskiejęzyki. Ojęzykach zawodowych i środowiskowych. Materiały VII Forum Kultury Stowa Gdańsk, 9-11 października 2008 roku. Gdańsk: Wydawnictwo Uniwersytetu Gdańskiego, s. 139-175.

Kołaczyk, Z. 1999. Rachunkowość finansowa. Poznań: Wydawnictwo Akademii Ekonomicznej.

Ligara, B., Szupelak, W. 2012. Lingwistyka i glottodydaktyka języków specjalistycznych na przykładzie języka biznesu. Podejście porównawcze. Kraków: Księgarnia Akademicka.

Lukszyn, J. 2002. Uniwersalia tekstów specjalistycznych. w: Lewandowski, J . (red.) Języki Specjalistyczne 2. Problemy technolingwistyki. Warszawa: Katedra J ęzyków Specjalistycznych UW, s. 41-48.

Lukszyn, J. (red. nauk.) 2005. Języki specjalistyczne. Slownik terminologii przedmiotowej. Warszawa: Katedra J ęzyków Specjalistycznych UW.

Lukszyn, J., Zmarzer, W. 2006. Teoretyczne podstawy terminologii. Warszawa: Katedra J ęzyków Specjalistycznych UW.

Łyda, A. 1997. Wzorce leksykalne w języku biznesu. w: Arabski, J. (red.) J ęzyki specjalistyczne - język biznesu. Materiały konferencyjne. Katowice: Wyższa Szkoła Zarządzania Marketingowego i J ęzyków Obcych w Katowicach, s. 5360 . 
Mamet, P. 1997. „Język biznesu” - próba zdefiniowania pojęcia dla celów dydaktyki języka obcego. w: Arabski, J . (red.) J ęzyki specjalistyczne - język biznesu. Materiały konferencyjne. Katowice: Wyższa Szkoła Zarządzania Marketingowego i J ęzyków Obcych w Katowicach, s. 61-74.

Mamet, P. 2002. Relacja pomiędzy kompetencją językową a kompetencją merytoryczna na przykładzie języka biznesu. w: Lewandowski, J. (red.) J ęzyki Specjalistyczne 2. Problemy technolingwistyki. Warszawa: Katedra J ęzyków Specjalistycznych UW, s. 141-151.

Nagórka, P. 2011. Struktura wiedzy zawodowej. w: Zmarzer, W. (red.) Języki wiedzy. Warszawa: Instytut Rusycystyki Uniwersytetu Warszawskiego, s. 6995.

Nęcki, Z. 1994. Negocjacje w biznesie. Kraków: Wydawnictwo Profesjonalnej Szkoły Biznesu.

Pomykało, W. (red.) 1995. Encyklopedia biznesu, t. 1. Warszawa: Fundacja Innowacja.

Potocki, A., Winkler, R., Żbikowska, A. 2011. Komunikowanie w organizacjach gospodarczych. Warszawa: "Difin".

Wilk-J anik, J. 2000. J ęzyk biznesu: jego cechy i implikacje dla glottodydaktyki. „Neofilolog”, nr 19, s. 177-184. 